\title{
Efficiency of using cables on 6-110 kV with sticked polyethylene isolation
}

\author{
Michail Korotkevich ${ }^{1 *}$, Sergey Podgaisky ${ }^{2}$, Andrey Golomuzdov ${ }^{2}$ \\ ${ }^{1}$ Belarusian National Technical University, Minsk, Republic of Belarus \\ 2 JSC “Energokomplekt” Industrial Association, Vitebsk, Republic of Belarus
}

\begin{abstract}
The expediency of using more expensive 6-10 kV cables with XLPE insulation was proved by us on the basis of the method of multi-purpose optimization, which took into account both the resulted costs for the construction and operation of cable lines, and the reliability of its operation, as well as the convenience of installation. Without compensation of capacitive currents, permissible difference in the height of the cable laying, the effect of cable lines on the environment.
\end{abstract}

\section{Introduction}

The expediency of using more expensive cables with XLPE insulation in comparison with cables with paperand-oil insulation will be considered for cable lines made with cables:

- three-core cross-sectional area of conductors $35-240 \mathrm{~mm}^{2}$ with a voltage of $6-35 \mathrm{kV}$;

- single-core cross-sectional area of conductors $35-240 \mathrm{~mm}^{2}$ (cables with XLPE insulation) and threecore with the same cross-sectional area of wires (cables with paper-and-oil insulation) with a voltage of $6-35 \mathrm{kV}$;

- single-core cross-sectional area of strands $150-630 \mathrm{~mm}^{2}$ (cables with XLPE insulation) and singlecore cross-sectional conductors (oil-filled cables with paper-oil insulation) with a voltage of $110 \mathrm{kV}$.

To assess the indicated expediency of using power cables with XLPE insulation in relation to cables with impregnated paper insulation, we will use both the reduced cost method and the multi-purpose optimization method, which allows taking into account not only the cost but also the quality indicators.

\section{The resulted annual costs for the construction and operation of cable lines}

Consist of the costs for the construction of the cable line $\mathrm{K}_{\text {к.л. }}$ and the cost of its operation И, i.e.

$$
3=\mathrm{E}_{\mathrm{\kappa}} \mathrm{K}_{\mathrm{\kappa} . \mathrm{r}}+\mathrm{U}
$$

where $E_{К}$ - coefficient of efficiency of capital investments (with refinancing rate of the National Bank of the Republic of Belarus equal to $14 \%$, value $\mathrm{E}_{\mathrm{K}}=0,14$ ).

Capital costs for the cable line construction $\mathrm{K}_{\text {к.л }}$ are comprised of the cost of purchasing the cable $K_{\mathrm{K}}$ and the cost of its installation $\mathrm{K}_{\mathrm{r}}$. In the total cost of building cable lines, the cost of cables is on average $48 \%$ for
6-10 $\mathrm{kV}$ lines; $57.5 \%$ for $35 \mathrm{kV}$ lines [1], $23-52 \%$, or an average of $37,5 \%$ for lines with a voltage of $20 \mathrm{kV}$ [2] and $33 \%$ for lines with a voltage of $110 \mathrm{kV}$ [1], i.e. $\mathrm{K}_{\mathrm{K}} / \mathrm{K}_{\mathrm{K} . \mathrm{J}}=0.48 ; 0.375 ; 0.575 ; 0,33$ - respectively for cable lines with voltage $6-10,20,35$ and $110 \mathrm{kV}$.

The cost of laying three-core cables with viscous or artificial insulation can be considered equal, and equal to $52 ; 62.5 ; 42.5 ; 67 \%$ of the total cost of the cable line, respectively, for lines with a voltage of $6-10 ; 20 ; 35$ and $110 \mathrm{kV}$. Here the cost of laying was estimated as

$$
\mathrm{K}_{\text {п }}=\left(1-\frac{\mathrm{K}_{\mathrm{K}}}{\mathrm{K}_{\text {к.л }}}\right) \mathrm{K}_{\text {к.л }}
$$

The ratio of the cost of building a cable line with cables with XLPE insulation $\mathrm{K}_{\mathrm{\kappa} . л}^{\mathrm{I}}$ to the cost of building a cable line with cables with paper-oil insulation $\mathrm{K}_{\text {к.л }}$ can be represented as

$$
\frac{\mathrm{K}_{\text {К.л }}^{\Pi}}{\mathrm{K}_{\text {к.л }}}+1+\frac{\alpha_{2}-1}{\alpha_{1}}
$$

where the coefficient taking into account the number of times the cost of building a cable line exceeds the cost of the cable itself; the value of $\alpha 1=2.08 ; 2.67 ; 1.74$; 3,3 - respectively, for lines with a voltage of $6-10 ; 20$; $35 ; 110 \mathrm{kV}$; a factor that takes into account the increase in the cost of a cable with XLPE insulation compared to the cost of a cable with combined insulation.

It is established from the expression (3) that the increase in the cost of a cable with XLPE insulation in comparison with the cost of a cable with paper-oil insulation in 1,2, ..., 2,0 times (i.e., $\alpha 2=1,2-2,0$ ) will lead to an increase in the cost of building a line with XLPE insulated cable in $1,1, \ldots, 1,48 ; 1.07, \ldots, 1.37 ; 1.11, \ldots$, $1.57 ; 1.06, \ldots, 1.3$ times, respectively, for lines with a voltage of $6-10 ; 20 ; 35 ; 110 \mathrm{kV}$.

When comparing the capital costs for the construction of a cable line with single-core cables with XLPE insulation and with three-core cables with paper-and-oil 
insulation, one must bear in mind both an increase in the cost of rolling three cables and a reduction in the cost of laying cables with XLPE insulation at the expense of :

- a smaller mass of drums with a cable, exported to the track;

- the need to install a smaller number of couplings due to large cable lengths;

- smaller diameter of each of the single-core cables compared to a three-core paper-insulated cable;

- a smaller permissible bending radius in comparison with three-core cables with an aluminum shell;

- there is no need to warm up the cable when installing in a negative temperature environment.

When assessing the cost of cables with XLPE insulation, it is necessary to take into account the fact of increasing the cable capacity due to the increase (up to $90 \mathrm{C}$ ) of the permissible heating temperature of the cores $[3,4]$.

The increase in the long-term permissible current corresponds, as it were, to an increase in $\delta \mathrm{F}$ of the required cross-sectional area of the cable cores, i.e.

$$
\delta \mathrm{F}=\frac{1}{\mathrm{j}_{\mathrm{H}}}\left(\mathrm{I}_{д}^{\mathrm{I}}-\mathrm{I}_{д}\right)
$$

where $j_{H}$ - is the normalized current density; for cables with paper insulation with aluminum or copper conductors; take 1.4 or $2,5 \mathrm{~A} / \mathrm{mm}^{2}$ (with the number of hours of use of the maximum load of 3000-5000 h [5]); $I_{д}^{\Pi}, I_{д}$ - long-lasting current for cables with polyethylene and paper insulation.

The values of the proportion of the increase in the cross-sectional area of cables with XLPE insulation as compared to cables with traditional insulation are:

- when comparing three-core cables with a voltage: $10 \mathrm{kV}(0,07-0,21)$ (copper cores); $(0,11-0,28)$ (aluminum core); (the lower values for the section are $240 \mathrm{~mm}^{2}$, the upper ones are $\left.70 \mathrm{~mm}^{2}\right) ; 20 \mathrm{kV}(0,17-0,27)$ (copper cores); $(0,25-0,45)$ (aluminum core); (the lower values for the section are $185 \mathrm{~mm}^{2}$, the upper ones are $\left.70 \mathrm{~mm}^{2}\right)$; $35 \mathrm{kV} \quad(0,20-0,24)$ (copper conductors); $(0,28-0,36)$ (aluminum core); (the lower values for the section are $150 \mathrm{~mm}^{2}$, the upper ones are $120 \mathrm{~mm}^{2}$ );

- when comparing three-core cables with paper insulation and single-core cables with XLPE insulation: $10 \mathrm{kV} \quad(0,13-0,34)$ (copper conductors); (0,09-0,45) (aluminum core); $20 \mathrm{kV}(0,24-0,42)$ (copper cores); $(0,34-0,61)$ (aluminum core); $35 \mathrm{kV}(0,27-0,33)$ (copper conductors); $(0,39-0,46)$ (aluminum core); here the upper and lower values refer to the same sections as above;

- when comparing single-core cables at a voltage of $110 \mathrm{kV}(0,12-0,32)$ (copper cores); 0,19 - aluminum conductors; (lower values for section $630 \mathrm{~mm}^{2}$, upper $150 \mathrm{~mm}^{2}$ ).

The cost per unit length of cable with polyethylene insulation $\mathrm{K}_{\mathrm{K}}^{\mathrm{II}}$

$$
\mathrm{K}_{\text {к }}^{\text {П }}=\mathrm{K}_{\text {из }}^{\text {П }}+\mathrm{F}(1-\sigma) \gamma \mathrm{c} \cdot 10^{-6}
$$

where $K_{\text {из }}^{\Pi}=G_{\text {из }} c_{\text {из }}$ - the cost of polyethylene insulation; $\mathrm{G}_{\text {из }}$ is the mass of insulation, $\mathrm{kg}$; $\mathrm{c}_{\text {из }}$ - the cost of one kilogram of insulation; is approximately equal to 209 s.m.u/kg; c - the cost per unit of mass of the core (equal to 1,94 and 5,37 s.m.u./kg respectively for aluminum and copper, respectively); $\gamma$ - specific volumetric weight or density of the vein material (for copper is equal to $8890 \mathrm{~kg} / \mathrm{m}^{3}$, aluminum - $2703 \mathrm{~kg} / \mathrm{m}^{3}$ ); F - crosssectional area of the cable core, $\mathrm{mm}^{2 ;} \sigma$ coefficient less than 1, taking into account the increase in the capacity of cables with polyethylene insulation by increasing the permissible temperature of heating the veins; (the limits of the change in the cross-sectional area of the wires are given above).

The cost of thecopper core material exceeds the cost of polyethylene insulation in $(1,8-19,7)$ times, the cost of the aluminum core material - in $(1,1-1,9)$ times. The cost of an aluminum core material with a cross section of $150-630 \mathrm{~mm}^{2}$ for $110 \mathrm{kV}$ cables is approximately equal to the cost of a cross-linked polyethylene insulation. With a cross-sectional area of aluminum veins up to $70 \mathrm{~mm}^{2}$, the material cost of veins is less than the cost of insulation. The ratio of the cost of material and fabrication of cores to the cost of material and the manufacture of cable insulation can lie within (0,1-1.0).

Through cable lines with cables with XLPE insulation, compared to paper-and-oil-insulated cable lines, operating costs are reduced by unnecessary of:

- mapping of soil corrosion zones;

- coating with anticorrosion varnishes and paints of non-zinced steel armor cables laid in cable structures;

- periodic replacement of vertical sections of cable lines due to dehumidification;

- monitoring the pressure and sampling of oil from oil-filled cable channels and couplings to determine the characteristics of the oil and the presence of undissolved air in it; monthly inspections of the feeding points (for oil-filled lines with a voltage of $110 \mathrm{kV}$ );

- periodic (on average, once every 1,8 years) isolation tests with an increased rectified voltage (here it is recommended to conduct a measurement of the dielectric permittivity of insulation against the applied voltage and frequency every 5 years);

- replacement of end couplings after 20 years of operation.

As a result, the cost of maintaining cable lines with XLPE insulation can be reduced compared to the associated costs of servicing paper-oil-insulated cable lines to:

$9 \%$ for cable lines with a voltage of $35 \mathrm{kV}$;

$17 \%$ for cable lines with a voltage of $110 \mathrm{kV}$.

Nevertheless, the costs for the construction and operation of XLPE insulated cable lines exceed the same costs for cable lines with paper-oil insulation in $(1,03-1,43)$ times.

\section{Integrated assessment of the feasibil- ity of using cables with XLPE insulation}

A comprehensive assessment of the feasibility of using cables with XLPE insulation is given using the multitarget optimization method.

It should be noted that single-core oil-filled cables with paper insulation for $110 \mathrm{kV}$ are currently not manufactured by industry and their presence in this report is of only methodological importance. In terms of the method 
of multi-purpose optimization, the problem is formulated as follows: it is necessary to evaluate the feasibility of using cables with XLPE insulation for a voltage of 6-110 kV in comparison with cables with paper-oil insulation when achieving the following objectives:

- the minimum of the resulted costs for the construction and operation of cable lines (target № 1);

- maximum reliability of work (target № 2);

- maximum ease of installation (goal № 3);

- the maximum length of the line without charging power compensation (target № 4);

- the maximum permissible difference in the height of the cable laying (target № 5);

- minimal impact on the environment (target № 6).

The expediency of using more expensive cables with XLPE insulation is ensured when the maximum optimization criterion $\mathrm{E} \rightarrow \max ,[6]$ is reached, i.e.

$$
\mathrm{E}=\sum_{\mathrm{i}=1}^{\mathrm{n}} \mathrm{v}_{\mathrm{i}} \mathrm{e}_{\mathrm{i}} \rightarrow \max
$$

where $v_{i}$ - is an estimate of the importance of the $i$-th goal, $\mathrm{i}=1, \ldots, \mathrm{n} ; \mathrm{e}_{\mathrm{i}}-$ is the relative effectiveness of the i-th goal.

A point estimate of the values of vi was obtained on the basis of the ranking of these goals by expertsspecialists in the design, construction and operation of networks, the total number of which was 32 .

The results of determining the importance of goals:

$\mathrm{v}_{1}=0,174 ; \mathrm{v}_{2}=0,281 ; \mathrm{v}_{3}=0,185 ; \mathrm{v}_{4}=0,1377 ;$ $\mathrm{v}_{5}=0,1155 ; \mathrm{v}_{6}=0,1066$.

To assess the trouble-free operation of cable power lines, the failure flow parameter $\lambda$ and the mean time between failures (inversely proportional to $\lambda$ ) are used. Experience in the operation of cable lines with cables with XLPE insulation showed that the failure flow parameter for such lines is an order of magnitude smaller, and the operating time for failure is an order of magnitude greater than for cable lines with paper-oil insulation.

Convenient installation of cable lines depends on the following factors, typical for cables with traditional insulation and insulation from cross-linked polyethylene: the mass of drums with cable, which must be taken out to the track for the subsequent installation of one kilometer line; outer diameter of the cable; permissible bending radius, allowable negative temperature of outside air, at which the cable is laid without its preheating.

We established [7] that the mass of drums with a three-core cable with aluminum conductors, lead sheath and paper-oil insulation impregnated with a non-sticking compound for a voltage of $10 \mathrm{kV}$ is greater than the weight of the drums with a three-core cable for the same voltage with XLPE insulation of approximately 1,3 times.

The weight of drums with a three-core cable with paper and oil insulation with aluminum cores and aluminum shells for voltage 6 and $10 \mathrm{kV}$ is less, and with a lead sheath greater than the mass of drums with a threecore cable with aluminum conductors and XLPE insulation approximately 1,12 times.

The weight of drums with a single-core cable with aluminum conductors with XLPE insulation is less than the weight of a three-core cable with paper insulation and with the same core material approximately in 1,09-1,5 times.

The weight of drums with single-core copper oilfilled $110 \mathrm{kV}$ cable is 1,36 times higher than with copper single-core cable with XLPE insulation.

The diameter of three-core cables with a voltage of $10 \mathrm{kV}$ and paper insulation is less than the diameter of the same cables with XLPE insulation of approximately 1,23 (ААБ and АПвП cables) and 1,16 (cables of the ЦАСБ and АПвП type) times or an average of 1,2 times.

The diameter of single-core oil-filled cable with paper insulation for $110 \mathrm{kV}$ is more in 1,1-1,15 times the diameter of the cable at the same nominal voltage with XLPE insulation.

The diameter of three-core cables with a voltage of $10 \mathrm{kV}$ and paper insulation is greater than the diameter of a single-core cable with XLPE insulation in 1,75 (AAB and APVP cables) and 1.83 (cables of the CASB and APVP type) times or an average of 1,8 times.

Three-core cables with polyethylene insulation have a smaller permissible bending radius in comparison with three-core cables with paper insulation in:

1,5 times - for cables with a lead sheath;

2,5 times - for cables with aluminum sheath.

Single-core cables with polyethylene insulation have a smaller (1,7 times) permissible bending radius in comparison with three-core cables with paper insulation and aluminum shells.

The possible temperature range at which the cable is laid without its preheating:

- cables with paper-oil insulation $-41^{\circ} \mathrm{C}$ (from 0 to $\left.+40^{\circ} \mathrm{C}\right)$

- cables with polyethylene insulation $-61^{\circ} \mathrm{C}$ (from minus 15 or $20^{\circ} \mathrm{C}$ to $+40^{\circ} \mathrm{C}$, including $0^{\circ} \mathrm{C}$ ). Therefore, the maximum temperature range at which the cable is laid without its preheating, for cables with polyethylene insulation is 1,4 times greater than for cables with paperoil insulation.

Estimation of the level of convenience of installation will be given on the basis of the method of multi-purpose optimization with the same importance for all purposes ( vi $=0,25)$, when it is necessary to ensure:

- minimum weight of drums with cable;

- the minimum outer diameter of the cable;

- the minimum radius of bending;

- the maximum permissible temperature range when laying the cable without preheating it.

Relative values of targets for cables with paper-oil insulation are taken as one; for cables with XLPE insulation were determined relative to the ones taken for the unit.

The relative effectiveness of the ei goals was calculated using the formulas:

- for minimized targets

$$
e_{i}=\frac{\min _{i}}{x_{i}},
$$

- for maximized goals 


$$
\mathrm{e}_{\mathrm{i}}=\frac{\mathrm{x}_{\mathrm{i}}}{\operatorname{maxx}_{\mathrm{i}}},
$$

where $x_{i}$ is the current value of goal indicators; $\min x_{i}$, $\operatorname{maxx}_{\mathrm{i}}-$ minimum and maximum values of target indicators. With the same importance of all goals, the value of the optimization criterion E (formula (6)) is calculated as

$$
\mathrm{E}=\frac{1}{4} \sum_{\mathrm{i}=1}^{4} \mathrm{e}_{\mathrm{i}}
$$

For three-core cables with XLPE insulation $(\mathrm{E}=0,95)$, the installation of the cable is large by 1,2 times (compared to the installation of a cable type ААБ and ЦАСБ) convenience.

Installation of a single-core cable with XLPE insulation for $10 \mathrm{kV}$ voltage is 1,4 and 1.6 times more convenient, respectively, compared to the installation of threecore cables of the ААБ and ЦАСБ type having paper-oil insulation.

Installation of a line of single-core cables with XLPE insulation for $110 \mathrm{kV}$ voltage is 1,4 times more convenient than installing a single-core oil-filled cable with paper insulation for the same voltage.

It is known $[8,9]$ that the value of the charging current is lower for cables with polyethylene insulation (because of the lower value of the working capacity compared to cables with paper-oil insulation), the value of the dielectric power losses taken into account for $110 \mathrm{kV}$ cables is almost an order of magnitude lower $\mathrm{kV}$.

Compensation of capacitive currents of a singlephase earth fault in electrical networks with a voltage of $6 ; 10 ; 20 ; 35 \mathrm{kV}$ should be provided when the value of these currents exceeds $30 ; 20 ; 15 ; 10$ A respectively.

The limiting length of cable lines with cables with polyethylene insulation is 1,5 times the permissible length of lines with cables with paper-oil insulation by the condition of operation without compensation for capacitive earth-fault currents and is equal to the ratio of the relative dielectric permeability of paper-oil insulation equal to 3,5 , to the relative dielectric permeability of cross-linked polyethylene equal to 2,3.

Cables with XLPE insulation allow an unlimited difference in height of the gasket, while the allowable difference in cable heights with paper-and-oil insulation is $15 \mathrm{~m}$.

The unlimited difference in height of the cable laying with polyethylene insulation in comparison with cables with paper-oil insulation can be numerically described as follows

$$
\delta \mathrm{h}=\mathrm{A} \lg \frac{\mathrm{h}^{\mathrm{\Pi}}}{\mathrm{h}}
$$

where $\delta \mathrm{h}$ - is an estimate of the increase in cable routing height with cross-linked polyethylene insulation; $h^{\Pi}$, $\mathrm{h}$ - is the permissible difference in cable routing heights with XLPE insulation (for the conditions of the Republic of Belarus more than $1000-1500 \mathrm{~m}$ is not required) and the permissible difference in cable heights with paperand-oil insulation; (equal to $15 \mathrm{~m}$ ).

Given the extreme values of $h^{\Pi}$ and $h$, their ratio is 100 and the value of $\delta h=2 A$. For $A=1, \delta h=2.0$.
The operation of cable lines is accompanied by the influence of the environment on them and the influence of cable lines on the environment (land, water, air).

Nature and external factors limit the conditions for laying cables:

- with XLPE insulation and polyvinyl chloride outer sheath - the value of soil moisture;

- with paper impregnated insulation - the values of corrosive (acidic, alkaline) soil activity, vibration.

In general, it can be said that the environment equally affects the cable lines, regardless of the insulation material of the cables and this effect is reflected in the reliability of cable lines.

Consider the influence of underground cable lines on the environment.

On the lines of cable lines, agricultural work is allowed, but the construction of houses and planting of large trees is excluded.

The electrical and magnetic fields around the cable line even at $500 \mathrm{kV}$ are insignificant. However, when the cable is operating, its surface is heated to a temperature of $50-55^{\circ} \mathrm{C}$ or $70-75^{\circ} \mathrm{C}$ (cables with paper-oil and polyethylene insulation, respectively), which leads to soil drying and has negative effects on living organisms living there. the surface of cables with XLPE insulation is heated 1,4 times more than the surface of paper-insulated cables.

The peculiarity of using a cable with XLPE insulation, compared to cables with paper-oil insulation, is that they do not have a liquid dielectric that can flow into the soil when performing repair work on $6-35 \mathrm{kV}$ lines or leak out of pressure tanks, pipelines, end, connecting and locking clutches on lines with oil-filled cables with a voltage of $110 \mathrm{kV} \mathrm{[10].}$

The absence of oil leakage from the cross-linked polyethylene insulation of the cable in terms of environmental impact will be estimated by the coefficient 2 (as well as by formula (10)), i.e. Damage to the environment will be 2 times less than for cables with traditional insulation.

When operating cable lines with cables that have a toxic lead sheath, additional costs are required for the rehabilitation of workers in contact with lead. Impact of lead on the environment refers to the high (third) level.

Cables with XLPE insulation can have a weakly toxic PVC jacket, the decomposition products of which cause irritation of the upper respiratory tract of the person and mucous membranes of the eye and relate to the average (second) level of environmental impact.

The foregoing allows us to establish the correlation of the factors of the effect of cable lines with paper and artificial insulation on the environment, i.e.

$$
\frac{И_{\text {окр }}^{\text {п }}}{И_{\text {окр }}}=\frac{И_{1}^{\text {п }}}{И_{1}} \frac{И_{2}^{\text {I }}}{И_{2}} \frac{И_{3}^{\text {П }}}{И_{3}}=+1,4 \frac{1}{2} \cdot \frac{2}{3}=0,47
$$

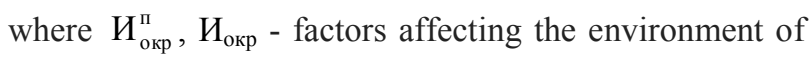
cable lines with polyethylene and paper-oil insulation; $И_{1}^{\Pi}, И_{1}$ - annual expenses for the reproduction of natural resources associated with heating the soil with cables with polyethylene and paper-oil insulation; $И_{2}^{\Pi}$ and $U_{2}$ - annual expenses on reproduction of the natural re- 
sources connected with leakage of oil oil in soil; $И_{3}^{\Pi}, И_{3}$ - annual costs associated with the work of personnel with toxic (lead and polyvinylchloride) materials. In the absence of polyvinyl chloride shell $И_{\text {окр }}^{\Pi}=0,35 И_{\text {окр }}$.

It follows from expression (11) that the effect of cables with polyethylene insulation on the environment will be less than that of cables with paper-oil insulation more than 2 times.

For a comprehensive assessment of the efficiency of using 6-110 kV cables with XLPE insulation, we use the method of multi-purpose optimization and the above formulation of the problem.

The value of targets in relative units for three-core and single-core cables with paper-oil insulation will be taken as one. The cost of a cable with XLPE insulation is more than twice the cost of a cable with paper-and-oil insulation.

The values of the relative effectiveness of goals are determined by the formulas (7), (8), and the optimization criterion - according to the formula (6) with the values of the importance of goals.

The values of the optimization criterion $\mathrm{E}$ for cables with paper insulation and XLPE insulation are shown in Table 1.

Table 1 - Values of the optimization criterion

\begin{tabular}{|c|c|c|c|}
\hline \multirow[t]{2}{*}{ Name of cables } & \multicolumn{3}{|c|}{ Optimization criteria for cables } \\
\hline & ААБ & ЦАСБ & АПвП \\
\hline $\begin{array}{l}\text { 1. Three-core } \\
\text { cables for } 10 \mathrm{kV}\end{array}$ & 0,558 & 0,615 & 0,959 \\
\hline $\begin{array}{l}\text { 2. Three-core } \\
\text { cables with pa- } \\
\text { per-oil insulation } \\
\text { and single-core } \\
\text { cables with } \\
\text { XLPE insulation } \\
\text { for } 10 \mathrm{kV}\end{array}$ & 0,536 & 0,579 & 0,959 \\
\hline $\begin{array}{l}\text { 3. Single-core oil- } \\
\text { filled cables with } \\
\text { paper-oil insula- } \\
\text { tion type MHC } \\
\text { and single-core } \\
\text { cables with } \\
\text { XLPE insulation } \\
\text { type ПвП for } 10 \\
\mathrm{kV}\end{array}$ & $\begin{array}{c}0,536 \\
(\mathrm{MHC})\end{array}$ & - & $\begin{array}{r}0,967 \\
(П в \Pi)\end{array}$ \\
\hline
\end{tabular}

As can be seen from the data in Table 1, the value of the optimization criterion characteristic of cables with XLPE insulation exceeds the corresponding value of the optimization criterion for cables with paper-and-oil insulation in 1,6-1,8 times, which means the unconditional efficiency of using cables with insulation from crosslinked polyethylene in comparison with cables with paper-oil insulation.

\section{Conclusion}

The expediency of using more expensive $6 \ldots 110 \mathrm{kV}$ cables with XLPE insulation was proved by us on the basis of the method of multi-purpose optimization, which took into account both the resulted costs for the construction and operation of cable lines, and the reliability of its operation, as well as the convenience of installation. Without compensation of capacitive currents, permissible difference in the height of the cable laying, the effect of cable lines on the environment.

\section{References}

1. V. A. Kozlov The Power Supply of Cities. (Leningrad, Energiya Publ. 280. 1977).

2. A. V. Maiorov, A. V. Shuntov. Methodical Problems of Research of Reliability of Large Energy Systems. Issue 66: Topical Problems of Reliability of Energy Systems. Minsk, BNTU, p.125-132 (2015)

3. Rules for Eleecrical Units Installation. (Moscow, Energoatomizdat Publ. 646 p. 1987).

4. The Cables and Wires. The Product Catalog. (Vitebsk, "Energocomplekt" Production Association. 58 p. 2015).

5. Handbook on the design of electric power systems. (Moscow: Energoatomizdat, 1985. - 352 p).

6. Yu. B. Guk Reliability Analysis of Electrical Installations. (Leningrad, Energoatomizdat Publ., Leningrad Branch. 224 p. 1988).

7. M. A. Korotkevich Operation of Electric Networks. (Minsk, Vysheishaya Shkola Publ. 350 p. 2014).

8. A guide to high voltage electrical installations. (Moscow: Energoatomizdat, 1989. - 768 p).

9. B. Widy High voltage cable lines (Moscow: Energoatomizdat, 1983. - $232 \mathrm{p}$ ).

10. E.T. Larina Power cables and cable lines (Moscow: Energoatomizdat, 1984. - 368 p). 